\title{
HUBUNGAN PENERAPAN MANAJEMEN TERPADU BALITA SAKIT DENGAN PENCAPAIAN TARGET PENYAKIT DIARE DI WILAYAH KERJA PUSKESMAS PAMBOANG KABUPATEN MAJENE
}

\author{
Muhammad Irwan
}

Latar Belakang: Upaya pencegahan dan pemberantasan penyakit diare terutama diarahkan pada penurunan angka kematian akibat diare pada bayi dan balita melalui pokok penatalaksanaan penderita diare dengan pendekatan metode manajemen terpadu balita sakit yang mencakup penemuan penderita, diagnosa dini, terapi yang tepat dan segera, upaya pencegahan serta konseling terhadap ibubalita penderita diare (Depkes RI, 2002). Manajemen Terpadu Balita Sakit yang selanjutnya disebut MTBS merupakan suatu metode atau pendekatan sistem, dimana pemeriksaan dan pengobatan bayi dan balita dilakukan secara komprehensif dalam satu format dan kegiatan, sehingga dapat mengetahui dan mendeteksi penderita penyakit Pnemonia, Diare, Demam Berdarah Dengue, Campak, Malaria, Status Gizi, Infeksi telinga dan Status Imunisasi (Depkes RI, 2002).

\section{Kata kunci : Diare, Balita, MTBS}

\section{PENDAHULUAN}

Keberhasilan pembangunan nasional suatu bangsa ditentukan oleh ketersediaan sumber daya manusia (SDM) yang berkualitas, yaitu sumber daya manusia yang memiliki fisik yang tangguh, mental yang kuat dan kesehatan yang prima disamping penguasaan terhadap ilmu pengetahuan dan teknologi. Salah satu upaya untuk meningkatkan kualitas sumber daya manusia adalah dengan meningkatkan derajat kesehatan masyarakat.

Undang-undang Kesehatan Nomor 23 Tahun 1992 tentang Kesehatan menekankan pentingnya upaya peningkatan mutu pelayanan kesehatan, yang mengamanatkan bahwa mutu pelayanan kesehatan harus makin ditingkatkan, seiring dengan upaya memperluas pemerataan dan kesenjangan pelayanan kesehatan kepada masyarakat.

Melalui peningkatan kualitas kesehatan dan derajat kesehatan keluarga dan masyarakat yang antara lain ditentukan oleh derajat kesehatan ibu dan anak sebagai kelompok penduduk yang rawan dan strategis, bidang kesehatan difokuskan pada kegiatan program yang berdampak besar terhadap penurunan angka kematian ibu dan angka kematian bayi.

Salah satu penyebab utama kematian dan kesakitan pada bayi dan balita di negara berkembang termasuk Indonesia adalah Pnemonia, Diare, dan Deman Berdarah Dengue (DBD). Berdasarkan data WHO tahun 2000, dari 15 juta kematian yang diperkirakan terjadi di kalangan anak berusia di bawah lima tahun setiap tahunnya di negara berkembang kira-kira 4 juta kematian $(36,8 \%)$ disebabkan oleh penyakit diare (WHO, 2001).

Berdasarkan hasil Survey Demografi

Kesehatan Indonesia (SDKI) tahun 2003, Angka Kematian Ibu (AKI) di Indonesia mencapai 307/ 100.000 kelahiran hidup. Sedangkan Angka Kematian Bayi (AKB) mencapai 35/ 1000 kelahiran hidup, penyebab utama kematian bayi adalah Pnemonia, Diare dan Malaria (Depkes RI, 2002).

Upaya pencegahan dan pemberantasan penyakit diare terutama diarahkan pada penurunan angka kematian akibat diare pada bayi dan balita melalui pokok penatalaksanaan penderita diare dengan pendekatan metode manajemen terpadu balita sakit yang mencakup penemuan penderita, diagnosa dini, terapi yang tepat dan segera, upaya pencegahan serta konseling terhadap ibubalita penderita diare (Depkes RI, 2002). Manajemen Terpadu Balita Sakit yang selanjutnya disebut MTBS merupakan suatu metode atau pendekatan sistem, dimana pemeriksaan dan pengobatan bayi dan balita dilakukan secara komprehensif dalam satu format dan kegiatan, sehingga dapat mengetahui dan mendeteksi penderita penyakit Pnemonia, Diare, Demam Berdarah Dengue, Campak, Malaria, Status Gizi, Infeksi telinga dan Status Imunisasi (Depkes RI, 2002).

Penemuan penyakit diare pada balita di Sulawesi Barat dari tahun 2002 sampai tahun 2005 menunjukkan peningkatan yang cukup signifikan yaitu dari $76 \%$ menjadi $79 \%$. Sedangkan pada tahun 2006 sampai tahun 2007 
setelah pelaksanaan MTBS angka tersebut terus meningkat yaitu mencapai $87 \%$ per tahun (Dinkes sulbar 2007).

Angka penemuan kasus diare di Kabupaten Majene pada tahun 2001 adalah 75 $\%$ dari jumlah balita dan setelah pelaksanaan MTBS dari tahun 2002 sampai tahun 2007 angka tersebut meningkat mencapai $89 \%$ per tahun (Dinkes Majene, 2007).

Lokasi penelitian ini bertempat di Puskesmas Pamboang Kabupaten Majene, dimana berdasarkan data dari Dinas Kesehatan Kabupaten Majene sebelum pelaksanaan MTBS penemuan kasus diare di Wilayah Kerja Puskesmas Pamboang Kabupaten Majene masih rendah, tetapi setelah MTBS diterapkan Puskesmas Pamboang merupakan salah satu Puskesmas yang berhasil melaksanakan MTBS dengan angka penemuan kasus diare cukup tinggi.

Pada studi pendahuluan yang penulis laksanakan pada bulan Desember 2016 terhadap 8 pegawai Puskesmas Pamboang tentang pelaksanaan penerapan MTBS terhadap pencapaian target penyakit diare, diketahui sebanyak 6 orang menyatakan bahwa penerapan MTBS berpengaruh terhadap penemuan penyakit diare di Wilayah Kerja Puskesmas Pamboang Kabupaten Majene.

Berdasarkan latar belakang di atas, penulis tertarik untuk melaksanakan penelitian yang akan dituangkan dalam bentuk karya ilmiah

\section{HASIL DAN PEMBAHASAN}

\section{Analisa Univariat}

Analisa univariat dalam penelitian ini akan menggambarkan data demografi resonden dengan judul "Hubungan Penerapan Manajemen Terpadu Balita Sakit dengan Pencapaian Target Penemuan Pernyakit Diare di Wilayah Kerja Puskesmas Pamboang Kabupaten Majene".

\section{METODE PENELITIAN}

\section{Jenis dan Metode Penelitian}

Jenis penelitian yang digunakan pada penelitian ini adalah deskriptif analitik yaitu penelitian yang dilakukan untuk menganalisis dan menyajikan data secara sistematis sehingga dapat lebih mudah untuk dipahami dan disimpulkan (Badriah, 2006 : 16).

\section{Lokasi dan Waktu Penelitian}

Penelitian ini dilaksanakan di Puskesmas Pamboang Kab. Majene pada bulan Mei sampai Juni 2017.

Populasi dan Sampel Populasi

Pada penelitian ini adalah seluruh perawat dan bidan di Puskesmas Pamboang Kabupaten Majene yang berjumlah 25 orang.

Sampel

Pada penelitian ini sampelnya adalah seluruh perawat dan bidan yang berada di Puskesmas pamboamg yang berjumlah 25 orang

meliputi umur, pekerjaan, tingkat pendidikan, pengetahuan kepala keluarga serta kejadian diare.

Tabel 4.1 Distribusi Responden Menurut umur kepala keluarga di Wilayah Kerja Puskesmas

Pamboang Kabupaten Majene 2017

\begin{tabular}{|c|c|c|}
\hline Umur & f & \% \\
\hline$<20$ tahun & 6 & 4.0 \\
\hline $20-35$ & 14 & 18.7 \\
\hline$>35$ & 58 & 77.3 \\
\hline Total & $\mathbf{9 8}$ & $\mathbf{1 0 0 . 0}$ \\
\hline
\end{tabular}

Sumber : Data Primer, 2017 
Berdasarkan tabel 4.1 dari 78 / kepala keluarga yang menjadi responden di puskesmas Pamboang dominan yang berumur $>35$ tahun sebanyak 58 responden (77.3\%) sedangkan yang berusia 20-35 tahun sebanyak 14 orang responden $(18,7 \%)$ dan sisanya 6 orang responden $(4,0 \%)$ berumur $<20$. Pada penelitian ini apabila dilihat dari factor usia kabanyakan berusia 20-35 tahun, itu berarti mereka kebanyakan pada usia subur dan produktif.

Tabel : 4.2 Distribusi responden menurut tingkat pendidikan di Wilayah Kerja Puskesmas Pamboang Kabupaten Majene 2017

\begin{tabular}{|c|c|c|}
\hline $\begin{array}{c}\text { Tingkat } \\
\text { Pendidikan }\end{array}$ & F & \% \\
\hline SD & 27 & 27.6 \\
\hline SMP & 8 & 8.2 \\
\hline T.SD & 63 & 64.2 \\
\hline Total & 98 & 100.0 \\
\hline
\end{tabular}

\section{Sumber : Data Primer, 2017}

Pada tabel 4.2 menunjukkan bahwa dari 98 responden dengan latar belakang pendidikan tidak tamat Sekolah Dasar/ SD yaitu sebanyak 63 responden $(64.2 \%)$, sedangkan yang tamat SD sebanyak 27 responden $(27,6 \%)$, dan mencapai tingkat pendidikan Sekolah Menengah Pertama Atau SMP sebanyak 8 responden $(8.2 \%)$. Ini menunjukkan rata-rata tingkat pendidikan masyarakat di wilayah puskesmas Pamboang masih sangat rendah.

Tabel 4.3 Distribusi Responden Menurut Pekerjaan di Wilayah Kerja Puskesmas Pamboang Kabupaten Majene 2017

\begin{tabular}{|c|c|c|}
\hline Jenis Pekerjaan & f & \% \\
\hline Petani & 40 & 40.8 \\
\hline Swasta & 30 & 30.6 \\
\hline Tidak Bekerja & 28 & 28.6 \\
\hline Total & $\mathbf{9 8}$ & $\mathbf{1 0 0 . 0}$ \\
\hline
\end{tabular}

\section{Sumber : Data Primer, 2017}

Pada tabel 4.3 menunjukkan bahwa dari 98 responden, jenis pekerjaan yang paling banyak adalah petani sebanyak 40 responden
(40.8\%), dan swasta sebanyak 30 responden $(30.6 \%)$, sedangkan yang tidak bekerja sebanyak 28 responden (28.6\%). 
Tabel : 4.4 Distribusi responden menurut Pengetahuan tentang Pengertian air bersih di wilayah kerja Puskesmas Pamboang kabupaten Majene 2017

\begin{tabular}{|c|c|c|}
\hline $\begin{array}{c}\text { Pengetahuan } \\
\text { tentang syarat air } \\
\text { bersih }\end{array}$ & F & \% \\
\hline Baik & 18 & 18.95 \\
\hline Cukup & 21 & 21.05 \\
\hline Kurang & 59 & 60.00 \\
\hline Total & 98 & 100.0 \\
\hline
\end{tabular}

Sumber : Data Primer, 2017

Pada tabel 4.4 menunjukkan bahwa dari 98 responden, sebagian besar kepala keluarga memiliki tingkat pengetahuan tentang pengertian air bersih sudah cukup yaitu sebanyak 56 responden (57.90\%), tingkat pengetahuan baik sebanyak 20 responden (20.00\%), sedangkan tingkat pengetahuan kurang yaitu sebanyak 22 responden (22.10\%).

Tabel : 4.5 Distribusi responden menurut tingkat Pengetahuan tentang syarat air bersih di wilayah kerja Puskesmas Pamboang kabupaten Majene 2017

\begin{tabular}{|c|c|c|}
\hline $\begin{array}{c}\text { Pengetahuan tentang } \\
\text { Pengertian air bersih }\end{array}$ & f & \% \\
\hline Baik & 20 & 20.00 \\
\hline Cukup & 56 & 57.90 \\
\hline Kurang & 22 & 22.10 \\
\hline Total & $\mathbf{9 8}$ & $\mathbf{1 0 0 . 0}$ \\
\hline
\end{tabular}

Sumber : Data Primer, 2017

Pada tabel 4.5 menunjukkan bahwa dari 98 responden, sebagian besar kepala keluarga memiliki tingkat pengetahuan tentang syarat air bersih masih kurang yaitu sebanyak
59 responden $(60.00 \%)$, tingkat pengetahuan cukup sebanyak 21 responden $(21.05 \%)$, sedangkan tingkat pengetahuan baik yaitu sebanyak 18 responden (18.95\%).

Tabel : 4.6 Distribusi responden menurut tingkat Pengetahuan tentang sumber air bersih di wilayah kerja Puskesmas Pamboang kabupaten Majene 2017 


\begin{tabular}{|c|c|c|}
\hline $\begin{array}{c}\text { Pengetahuan tentang } \\
\text { Sumber air bersih }\end{array}$ & f & \% \\
\hline Baik & 19 & 18.95 \\
\hline Cukup & 57 & 58.95 \\
\hline Kurang & 22 & 22.10 \\
\hline Total & 98 & 100.0 \\
\hline
\end{tabular}

Sumber : Data Primer, 2017

Pada tabel 4.6 menunjukkan bahwa dari 98 responden, sebagian besar kepala keluarga memiliki tingkat pengetahuan tentang sumber air bersih sudah cukup yaitu sebanyak
57 responden $(58.95 \%)$, tingkat pengetahuan kurang sebanyak 22 responden $(22.10 \%)$, sedangkan tingkat pengetahuan baik yaitu sebanyak 19 responden (18.95\%).

Tabel : 4.7 Distribusi responden menurut tingkat Pengetahuan tentang Pengolahan air bersih di wilayah kerja Puskesmas Pamboang kabupaten Majene 2017

\begin{tabular}{|c|c|c|}
\hline $\begin{array}{c}\text { Pengetahuan tentang } \\
\text { pengolahan air bersih }\end{array}$ & f & \% \\
\hline Baik & 22 & 22.10 \\
\hline Cukup & 20 & 21.05 \\
\hline Kurang & 56 & 56.85 \\
\hline Total & 98 & 100.0 \\
\hline
\end{tabular}

Sumber : Data Primer, 2017

Pada tabel 4.7 menunjukkan bahwa dari 98 responden, sebagian besar kepala keluarga memiliki tingkat pengetahuan tentang syarat air bersih masih kurang yaitu sebanyak 56 responden $(56.85 \%)$, tingkat pengetahuan cukup sebanyak 20 responden (21.05\%), sedangkan tingkat pengetahuan baik yaitu sebanyak 22 responden $(22.10 \%)$.

Tabel : 4.8 Distribusi responden menurut tingkat Pengetahuan di wilayah kerja Puskesmas Pamboang kabupaten Majene 2017

\begin{tabular}{|l|c|c|}
\hline Pengetahuan & f & \% \\
\hline Baik & 6 & 6.1 \\
\hline Cukup & 44 & 44.9 \\
\hline Kurang & 48 & 49.0 \\
\hline
\end{tabular}




\begin{tabular}{|c|c|c|}
\hline Total & 98 & 100.0 \\
\hline
\end{tabular}

Sumber : Data Primer, 2017

Pada tabel 4.8 menunjukkan bahwa

(49.0\%), tingkat pengetahuan cukup sebanyak dari 98 responden, sebagian besar kepala 44 responden (44.9\%), sedangkan tingkat keluarga memiliki tingkat pengetahuan yang pengetahuan baik yaitu sebanyak 6 responden masih kurang yaitu sebanyak 48 responden $(6.1 \%)$

Tabel : 4.9 Distribusi Responden Menurut kejadian diare di wilayah kerja puskesmas Pamboang Kabupaten Majene 2017

\begin{tabular}{ccc}
\hline Kejadian Diare & f & \% \\
\hline Menderita & 68 & 69.4 \\
Tidak menderita & 30 & 30.6 \\
\hline Total & 98 & 100.0 \\
\hline
\end{tabular}

Sumber : Data Primer, 2017

Pada tabel 4.9 menunjukkan bahwa dari 98 responden, yang menderita diare yaitu sebanyak 68 responden (69.4\%), sedangkan yang tidak menderita yaitu hanya 30 responden

Analisa Bivariat

Pengaruh faktor tingkat pengetahuan kepala keluarga dalam penggunaan air bersih dengan
(30,6\%). Dimana hal ini berkaitan dengan pengetahuan masyarakat tentang penyebab diare masih dangat kurang

kejadian diare diwilayah kerja puskesmas Pamboang

Tabel : 4.10 Pengaruh faktor tingkat pengetahuan kepala keluarga dalam penggunaan air bersih dengan kejadian diare diwilayah kerja puskesmas Pamboang Kabupaten Polman 2017

\begin{tabular}{|c|c|c|c|c|c|c|}
\hline \multirow{3}{*}{$\begin{array}{c}\text { Tingkat } \\
\text { Pengetahuan }\end{array}$} & \multicolumn{4}{|c|}{ Kejadian Diare } & \multirow{2}{*}{\multicolumn{2}{|c|}{ Total }} \\
\hline & \multicolumn{2}{|c|}{ Menderita } & \multicolumn{2}{|c|}{$\begin{array}{c}\text { Tidak } \\
\text { menderita }\end{array}$} & & \\
\hline & $\mathbf{F}$ & $\%$ & $\mathbf{f}$ & $\%$ & f & $\%$ \\
\hline Baik & 0 & 0 & 6 & 20.0 & 6 & 6.1 \\
\hline Cukup & 22 & 32.4 & 22 & 37.2 & 44 & 44.9 \\
\hline Kurang & 46 & 67.6 & 2 & 6.8 & 48 & 49.0 \\
\hline Total & 68 & 100 & 30 & 100 & 98 & 100.0 \\
\hline
\end{tabular}

Sumber : Data Primer, 2017 
Pada Tabel 4.10 didapatkan bahwa dari 98 responden yang menderita diare, persentase tertinggi adalah kategori pengetahuan kurang yaitu sebanyak 46 responden (67.6\%), jika dibandingkan dengan kategori pengetahuan cukup yaitu sebanyak 22 responden (32.4\%) sedangkan yang berpengetahuan baik tidak ada atau $(0 \%)$. Sedangkan dari 30 responden yang tidak menderita diare, persentase tertinggi adalah kategori pengetahuan cukup yaitu sebanyak 22 responden (37.2\%), jika dibandingkan dengan kategori pengetahuan baik sebanyak 6 responden (20.0\%) dan yang

\section{Pembahasan}

Berdasarkan hasil analisis data dan disesuaikan dengan tujuan penelitian serta kerangka konsep penelitian, maka pembahasan di kemukakan sebagai berikut :

\section{Analisis hubungan pengetahuan kepala keluarga dalam penggunaan air bersih dengan kejadian diare di Puskesmas Pamboang Kecamatan Pamboang Kabupaten Majene.}

Pengetahuan Kepala keluarga terkait dengan sikap atau perbuatan melakukan sesuatu dalam kehidupannya. Menurut Bloom yang dikutip oleh Ngatimin, pengetahuan merupakan bagian dari knowledge, application, analysis, dan evaluation, dimana pengetahuan sangat penting dalam memberikan wawasan terhadap sikap atau perbuatan seseorang.

Pendapat lain disampaikan Notoatmodjo, bahwa pengetahuan tentang sesuatu menyebabkab seseorang mempunyai sifat positif yang akan mempengaruhi niat untuk melakukan suatu kegiatan. Perilaku yang didasari oleh pengetahuan akan lebih langgeng berpengetahuan kurang yaitu sebanyak 2 responden $(6.8 \%)$.

Untuk mengetahui pengaruh faktor pengetahuan kepala keluarga dalam penggunaan air bersih dengan kejadian diare maka dilakukan uji chi-square. Hasil analisa data dengan menggunakan uji chi-square maka di peroleh hasil $\mathrm{p}=0,000<\alpha \quad 0,05$ maka ini berarti $\mathrm{H}_{1}$ di terima dan $\mathrm{H}_{0}$ ditolak, maka ada hubungan antara Pengetahuan kepala keluarga dalam penggunaan air bersih dengan kejadian diare diwilayah kerja puskesmas Pamboang.

dibanding dengan perilaku tanpa didasari pengetahuan yang baik. Keterkaitan anatara pengetahuan dan sikap atau perbuatan seseorang atau kepala keluarga sangat berpengaruh dalam pengambilan keputusan guna menhindari terjadinya diare pada anggota keluarga lainnya.

Pengetahuan merupakan faktor yang sangat penting untuk terbentuknya tindakan seseorang. Karena jika seseorang tidak mengetahui sebuah obyek, obyek tersebut tidak akan menarik bagi seseorang. Begitu juga dengan kejadian diare, pada saat responden tidak mengetahui tentang penyebab diare dalam hal ini penggunaan air bersih baik defenisi, syarat, sumber dan pengolahan air bersih, maka responden, akan memandang sebelah mata terhadap fungsi dan manfaat air bersih Padahal Penggunaan air bersih mempunyai dampak pada kebersihan makanan dan minuman serta higiene perseorangan. Penggunaan air bersih berpengaruh baik terhadap kesehatan.

Pada tabel 4.8 menunjukkan bahwa dari 98 responden, sebagian besar kepala 
keluarga memiliki tingkat pengetahuan yang masih kurang yaitu sebanyak 48 responden (49.0\%), tingkat pengetahuan cukup sebanyak 44 responden (44.9\%), sedangkan tingkat pengetahuan baik yaitu sebanyak 6 responden (6.1\%). Dengan demikian responden dengan tingkat pengetahuan kurang lebih banyak dibandingkan dengan responden dengan tingkat pengetahuan cukup dan dan baik.

Menurut pengamatan peneliti, tahu atau tidak kepala keluarga tentang pengunaan air bersih dipengaruhi oleh berbagai faktor, salah satu diantaranya yaitu kurangnya informasi tentang pelayanan kesehatan di puskesmas baik itu diposyandu maupun di puskesmas itu sendiri. Latar belakang pendidikan dapat mempengaruhi sikap seseorang dalam mengambil keputusan. Berdasarkan distribusi pendidikan responden mayoritas latar belakang pendidikan masyarakat yang ada di wilayah Pamboang menunjukkan tingkat pendidikan yang masih sangat rendah dengan presentase pada tabel 4.2 yaitu dari sejumlah responden yang diteliti yang mempunyai tingkat pendidikan tidak tamat Sekolah Dasar/ SD yaitu sebanyak 63 responden $(64.2 \%)$, sedangkan yang tamat SD sebanyak 27 responden (27,6\%), dan mencapai tingkat pendidikan Sekolah Menengah Pertama Atau SMP hanya 8 responden (8.2\%). Sama halnya dengan pencegahan diare dimana Berdasarkan hasil penelitian mengatakan semakin rendah latar belakang pendidikan kecenderungan terjadi penolakan terhadap pengambilan sebuah keputusan yang dianggap tidak bernilai, hal ini faktor terpenting dari kejadian diare. Pengetahuan tentang penggunaan air bersih seperti syarat air bersig sumber air bersig sampai dengan pengolahan air bersih tergantung oleh banyaknya orang yang mendengar, melihat, mengikuti penyuluhan-penyuluhan oleh tenaga kesehatan, tokoh masyarakat dan sebagainya. Dengan pengetahuan diharapkan dapat mempengaruhi persepsi, sikap dan perilaku untuk lebih menerima dan mempunyai kemauan untuk mengimunisasikan bayi mereka untuk mewujudkan tujuan dari pemerintah dalam meningkatkan kesehatan individu, keluarga dan masyarakat.

Sesuai dengan prinsip teknologi tepat guna di pedesaan maka air minum yang berasal dari mata air dan sumur dalam dapat diterima sebagai air yang sehat dan memenuhi syarat sehat, asalkan tidak tercemar oleh kotoran terutama kotoran manusia dan binatang. Hal ini berbeda dengan penggunaan air di wilayah Pamboang yang mayoritas masyarakat memperoleh air untuk keperluan sehari-hari dari aliran sungai yang digunakan untuk mandi, mencuci dan dikomsumsi untuk keperluan minum (termasuk untuk memasak). (Puskesmas Pamboang, 2012)

Berdasarkan distribusi pengetahuan kepala keluarga tentang syarat air bersih yaitu sebagian besar kepala keluarga memiliki tingkat pengetahuan masih kurang yaitu sebanyak 59 responden (60.00\%), dibandingkan dengan yang berpengetahuan cukup sebanyak 21 responden (21.05\%), sedangkan pengetahuan baik yaitu sebanyak 18 responden $(18.95 \%)$. Notoatmodjo $(2002,153)$ menyatakan bahwa agar air minum tidak 
menyebabkan penyakit, maka air tersebut hendaknya diusahakan memenuhi persyaratanpersyaratan kesehatan.

Menurut Notoatmodjo (2002 : 155 158) ada beberapa cara pengolahan air minum salah satunya adalah Pengolahan Air dengan Memanaskan sampai Mendidih. Tujuannya untuk membunuh kuman-kuman yang terdapat pada air. Pengolahan semacam ini lebih cepat hanya untuk konsumsi kecil, misalnya untuk kebutuhan rumah tangga. Namun Berdasarkan distribusi responden/ kepala keluarga yang memilki pengetahuan tentang pengolahan air bersih masih kurang yaitu sebanyak 56 responden $(56.85 \%)$. Pengolahan air yang benar seringkali diabaikan oleh masyarakat khususnya yang berada di wilayah Pamboang yang umumnya mempunyai Sumber air minum dari sungai yang jelas tidak terlindungi (protected), sehingga air tersebut tidak atau kurang memenuhi persyaratan kesehatan. Perlu pengolahan terlebih dahulu sehingga $\mathrm{Hal}$ ini perlu perhatian khusus dari petugas setempat.

$$
\text { Dari hasil penelitian yang }
$$
menggunakan uji chi-square dengan tingkat kepercayaan $\alpha<0,05$ didapatkan ada hubungan antara tingkat pengetahuan kepala keluarga dengan kejadian Diare dengan p-Value 0,000.

Beberapa hal yang mempengaruhi penyakit Diare adalah pengetahuan Kepala keluarga sesuatu yang diketahui kepala keluarga tentang penyakit Diare, baik melalui tanda-tanda yang terlihat pada penderita, penyebab diare termasuk mengenai penggunaan air bersih serta pertolongan pertama, informasi maupun tempat pelayanan.

Pengetahuan adalah hal yang penting bagi setiap individu, karena modal pengetahuan seseorang bila bersikap atau melakukan sesuatu usaha termasuk melakukan usaha pencegahan dari berbagai penyakit seperti Diare. Hal ini perlu ditunjang oleh sejauh mana tingkat pengetahuan kepala keluarga agar permasalahan dapat dipahami.

Pada Tabel 4.10 didapatkan bahwa dari 98 responden yang menderita diare, persentase tertinggi adalah kategori pengetahuan kurang yaitu sebanyak 46 responden (67.6\%), jika dibandingkan dengan kategori pengetahuan cukup yaitu sebanyak 22 responden (32.4\%) sedangkan yang berpengetahuan baik tidak ada atau (0\%). Sedangkan dari 30 responden yang tidak menderita diare, persentase tertinggi adalah kategori pengetahuan cukup yaitu sebanyak 22 responden (37.2\%), jika dibandingkan dengan kategori pengetahuan baik sebanyak 6 responden (20.0\%) dan yang berpengetahuan kurang yaitu sebanyak 2 responden $(6.8 \%)$.

Berdasarkan hasil penelitian diketahui bahwa pada umumnya responden memiliki pengetahuan tentang penggunaan air bersih yang kurang terhadap kejadian diare pada keluarga

Hasil penelitian ini didukung oleh teori Kambu (2005) yang menyatakan bahwa memang ada hubungan antara pengetahuan dengan kejadian Diare. Responden yang memiliki pengetahuan baik akan mencegah 
timbulnya penyakit Diare pada keluarga dari pada responden yang memiliki pengetahuan kurang.

\section{KESIMPULAN DAN SARAN}

\section{Kesimpulan}

Dari hasil penelitian tentang "Faktorfaktor yang mempangaruhi rendahnya pemanfaatan posyandu oleh ibu balita di wilayah kerja Puskesmas Tutar Kabupaten Polewali Mandar tahun 2012 yang dilakukan pada tanggal 01 Maret sampai dengan Mei 2012 dengan jumlah sampel 100 responden. Dapat disimpulkan sebagai berikut :

Ada pengaruh antara faktor pengetahuan ibu bayi usia 0-9 bulan terhadap rendahnya pencapaian imunisasi polio diwilayah kerja Puskesmas Tutar dengan $\mathrm{p}=0,000<\alpha 0,05$ berarti Ha diterima H0 ditolak

Ada pengaruh antara faktor keterjangkauan sarana terhadap rendahnya pencapaian imunisasi polio diwilayah kerja Puskesmas Tutar dengan $\mathrm{p}=0,000<\alpha 0,05$ berarti Ha diterima $\mathrm{HO}$ ditolak

Ada pengaruh antara faktor dukungan keluarga terhadap rendahnya pencapaian imunisasi polio diwilayah kerja Puskesmas Tutar dengan $\mathrm{p}=0,000<\alpha 0,05$ berarti $\mathrm{Ha}$ diterima H0 ditolak

\section{Saran}

Bagi Puskesmas

Diharapkan kepada pihak Puskesmas Tutar Kabupaten Polewali Mandar agar menambah unit pelayanan kesehatan secara merata yang dapat dijangkau oleh masyarakat.
Diharapkan kepada pihak Puskesmas Tutar Kabupaten Polewali Mandar untuk memberikan penyuluhan-penyuluhan kesehatan khususnya imunisasi pada bayi dan balita di seluruh wilayah kerja puskesmas Tutar agar dapat meningkatkan pelayanan kesehatan pada masyarakat.

Bagi Responden

Bagi masyarakat di Kecamatan Tutar agar dapat memanfaatkan puskesmas khususnya Posyandu tidak hanya sebagai tempat berobat tetapi juga untuk mendapatkan informasi kesehatan.

\section{DAFTAR PUSTAKA}

Anne Mills dan Lucy Gilson, 1990 Ekonomi Kesehatan untuk Negara Berkembang, Dian Rakyat, Jakarta.

Arikunto, Suharsimi, 2002, Prosedur Penelitian, Suatu Pendekatan Praktek, Rineka Cipta, Jakarta.

Azwar, Azrul, 1996 Pengantar Administrasi Kesehatan, Binarupa Aksara, Cetakan ke-3, Jakarta.

Bachtiar A, 2002, Metodologi Penelitian Kesehatan, Universitas Indonesia, Jakarta

Budiarto. 2001. Biostatistika untuk Kedokteran dan Pengukurannya. Pustaka Pelajar, Yogyakarta

Brotosaputro, Budioro, 1998. Pengantar Pendidikan (Penyuluhan) Kesehatan Masyarakat, Badan Penerbit UNDIP, Semarang.

Depkes RI, 2000. Bimbingan dalam Tatalaksana Penderita Diare Pada Anak. Direktorat Jenderal P2M dan PLP, Jakarta.

2001. Berita Epidemiologi Bulletin, Edisi April, 7 - 8, Jakarta. 
2002. Pedoman Pemberantasan Penyakit Diare. Direktorat Jenderal P2M dan PLP, Jakarta.

2002. Pentingnya Kemitraan Dalam Penanggulangan Diare. Direktorat Jenderal P2M dan Penyehatan Lingkungan Pemukiman, Jakarta.

2002. Manajemen Terpadu Balita Sakit Seri 1-8, Jakarta.

2003. Panatalaksanaan Penyakit Diare. Direktorat Jenderal P2M dan Penyehatan Lingkungan Pemukiman, Jakarta.

2004. Pentingnya Kemitraan Dalam Penanggulangan Diare. Direktorat Jenderal P2M dan Penyehatan Lingkungan Pemukiman, Jakarta.

2003, Survei Kesehatan Rumah Tangga, Jakarta.

Dinkes Kabupaten Majene, 2011, Profil Kesehatan Kabupaten Majene Tahun 2011, Dinas Kesehatan Kabupaten Majene

Foster and Anderson, 1986 Antropologi Kesehatan, Penerbit Universitas Indonesia, Jakarta.

Murti, Bisma, 1995 Prinsip dan Metode Riset Epidemiologi, Gadjah Mada Univeresity Press, Yogyakarta.
Puskesmas Pamboang, 2010, Profil Kesehatan Puskesmas Pamboang Tahun 2010, Puskesmas Pamboang Kabupaten Majene.

SAM, Dadang. 2002. Rapid Etnografi Assesment, MTBS. Tasikmalaya

Smet, Bart, 1994. Psikologi Kesehatan, Gramedia Widiasarana Indonesia, Jakarta.

Soekidjo Notoatmodjo, dkk, 2002. Metodologi Penelitian Kesehatan, Rineka Cipta, Jakarta.

,2003 Pengantar Ilmu Perilaku Kesehatan, Badan Penerbit Kesehatan Masyarakat FKMUI, Jakarta.

Sudjana, Nana. Ibrahim, 1999, Penelitian dan Penilaian Pendidikan. Sinar Baru, Bandung.

Sugiyono, Eriwibowo, 2004. Statistika Penelitian dan Aplikasinya dengan SPSS 10,00 For Window, Alfabeta, Bandung

1997. Metode Penelitian Administrasi. Alfabeta, Bandung

Widjaja, M.C, 2003. Mengatasi Diare dan Keracunan pada Balita. Kawan Pustaka, Jakarta 